\title{
渡良瀬川・利根川・江戸川流域水道水の揮発性有機化合物
}

\author{
大道 公 秀*1, 大道 正 義*2, 町 田 和 彦*1 \\ ${ }^{*}$ 早稲田大学大学院人間科学研究科環境保健学 \\ *2千葉市環境保健研究所
}

\section{Volatile Organic Compounds of the Tap Water in the Watarase, Tone and Edo River System}

\author{
Kimihide OHMICHI*1, Masayoshi OHMICHI*2 and Kazuhiko MACHIDA*1 \\ ${ }^{*}$ Department of Hygiene and Public Health, Graduate School of Human Sciences, Waseda University, Saitama \\ ${ }^{* 2}$ Chiba City Institute of Health and Environment, Chiba
}

\begin{abstract}
Objectives: The chlorination of river water in purification plants is known to produce carcinogens such as trihalomethanes (THMs). We studied the river system of the Watarase, Tone, and Edo Rivers in regard to the formation of THMs. This river system starts from the base of the Ashio copper mine and ends at Tokyo Bay. Along the rivers, there are 14 local municipalities in Gunma, Saitama, Ibaragi and Chiba Prefectures, as well as Tokyo. This area is the center of the Kanto plain and includes the main sources of water pollution from human activities. We also analyzed various chemicals in river water and tap water to clarify the status of the water environment, and we outline the problems of the water environment in the research area (Fig. 1).

Methods: Water samples were taken from 18 river sites and $\mathbf{4 2}$ water faucets at public facilities in 14 local municipalities. We analyzed samples for volatile organic compounds such as THMs, by gas chromatography mass spectrometry (GC-MS), and evaluations of chemical oxygen demand (COD) were made with reference to Japanese drinking water quality standards.

Results: Concentrations of THMs in the downstream tap water samples were higher than those in the samples from the upperstream. This tendency was similar to the COD of the river water samples, but no correlation between the concentration of THMs in tap water and the COD in tap water sources was found. In tap water of local government $C$, trichloroethylene was detected.

Conclusions: The current findings suggest that the present water filtration plant procedures are not sufficient to remove some hazardous chemicals from the source water. Moreover, it was confirmed that the water filtration produced THMs. Also, trichloroethylene was detected from the water environment in the research area, suggesting that pollution of the water environment continues.
\end{abstract}

Key words: tap water（水道水), river water（河川水）, THMs（トリハロメタン）, volatile organic compounds（揮発性有機化合物）, water quality（水質）, trichloroethylene（トリクロロエチレン）

\section{緒言}

近年, 水道水中の微量有機物の存在が報告されており, なかでもトリハロメタンの污染問題はその発ガン性から も危惧されている(1-5)。トリハロメタンは浄水処理工

受付 2003 年 7 月 24 日, 受理 2003 年 11 月 18 日

Reprint requests to: Kimihide OHMICHI

Department of Bioenvironmental Medicine, Graduate School of Medicine, Chiba University, Chiba

TEL: +81(43)226-2017, FAX: +81(43)226-2018
程の塩素処理過程で, 原水のフミン質等の有機物（トリ ハロメタン前駆物質）と浄水場での塩素消毒による遊離 塩素が反応して生成される $(6,7)$ 。したがってトリハロ メタンの生成には当然水道水の原水である河川水含有物 の影響を受けることになる $(8)$ 。そこで本研究では水道 水中のトリハロメタンの生成に関して河川水の水質とを 関連させ調査した。

また先行研究に打いて一部地域の水道水中においてト

リクロロエチレン等揮発性有機化合物が検出されたこと を報告している $(9,10)$ 。これらは発ガン性をるつ化学物 
質であり（11）, 公衆衛生的見地から水道水に混在するこ とは防がねばならない。そこで，河川水・水道水につい てトリクロロエチレンなど揮発性有機化合物の分析も併 せて行った。

渡良瀬川・利根川・江戸川流域河川は北関東地域を支 える水源として, 生活用水, 工業用水, 農業用水として 幅広く利用される貴重な水資源である。人間の諸活動に よる河川水の污染は，それを水源とする水道水の污染を 引き起こす要因だと考えられる(10)。そこで本研究では 渡良瀬川・利根川・江戸川流域自治体水道水の水質と河 川水等の水道原水の水質とを関連させ水質衛生に関する 包括的な検討を試みた。水質衛生に関しては，河川水と 水道水についてそれぞれ単独の報告は見られるものの, これらを複合する本研究のような研究は例がないもので あり，また水道水は生命活動に不可欠な点からも現況を 明らかにすることは極めて重要である。我々は現時点で いくつかの知見を得たので報告する。

\section{方法}

渡良瀬川・利根川・思川・江戸川の河川を群馬県足尾 銅山のふもとから栃木県・埼玉県・茨城県・千葉県を経 て東京都へと至る河川に沿った 18 地点を採水地点とし て選び，これら河川流域 14 自治体から 42 地点の水道水 （Fig. 1 参照）を，2001 年 9 月 1, 2, 3 日・11 月 23, 24, 25 日・ 2002 年 2 月 $25,26,27$ 日及び 5 月 31 日， 6 月 1,2 日に ガラス瓶に採水し試料とした。

採水は雨天とその翌日は避けた。河川水の採水には八 イロート採水瓶を用いて流心より採水し, 試験用途別に 各容器に採取した。水道水は 3 分間程充分に流水し，水 道管内の置換を行い, いずれも衛生試験方法 (12) 及び上

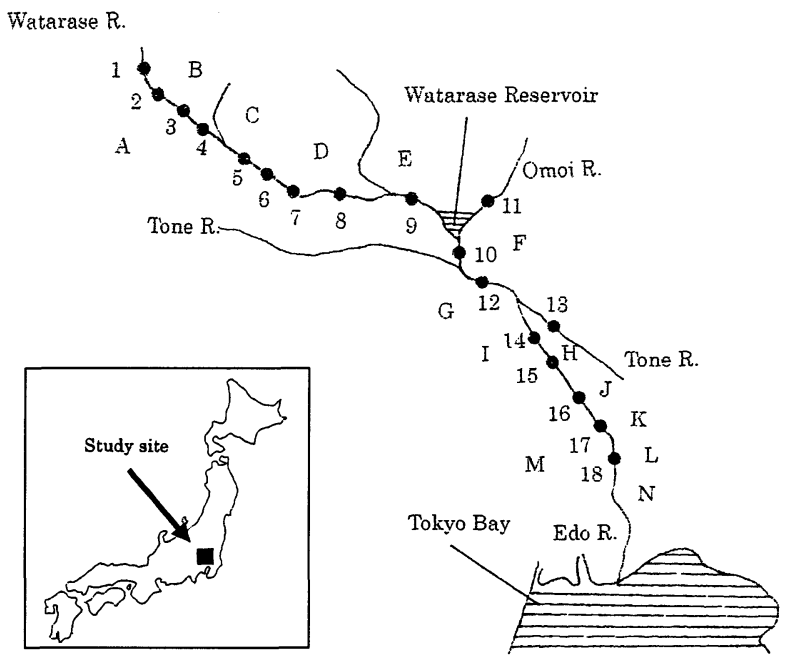

Fig. 1 Sampling stations along Watarase, Tone, and Edo river system are shown with numbers from 1 to 18 . The letters from $\mathrm{A}$ to $\mathrm{N}$ indicate the 14 local municipalities where tap water were taken.
水試験方法（13）などに定められた採水方法に準じて採 水した。

\section{揮発性有機化合物の測定}

試料採水瓶は, $100^{\circ} \mathrm{C} て ゙ 3$ 時間乾燥した後, $\mathrm{n}$-へキサン で洗浄し乾燥させたものを使用した（空気中に存在する 揮発性有機化合物が，試料採水瓶を污染するのを防ぐた めこの操作を行った。また水滴が残っている場合も污染 の原因となるので充分洗浄，乾燥を行った）。試料は，瓶 に泡立てないよらに静かに $100 \mathrm{ml}$ 容量の採水瓶に満水量 を採水し, $\mathrm{pH}$ が約 2 になるように $9 \%$ の塩酸水溶液を打 扣よそ試料 $10 \mathrm{ml}$ につき 1 滴加えて（トリハロメタン類は アルカリ性側に移行するに従って生成量が多くなるので この操作で生成を抑えた)，直ちに密栓し測定に供した。

測定はへッドスペース法によりガスクロマトグラ フィ一質量分析計（GC-MS）に試料を注入し SIM 法でフ ラグメントイオンをモニタリングした。各物質の保持時 間が標準物質と一致することを確認し，保持時間に相当 する各物質を定量した（Fig. 2）。

\section{COD の測定}

有機物の水質指標としての化学的酸素要求量（COD） を測定した。採水は充分洗浄した $500 \mathrm{ml}$ 容量ポリ容器に 満水量を採水し測定に供した。測定方法は過マンガン酸 カリウムによる酸素要求量を測定する方法 $(12,13)$ に準 じて測定した。また今回データでは示さないが，塩素イ オン濃度・残留塩素濃度についても公定法 $(12,13)$ に準 じて採水・測定した。

\section{結果}

\section{1. 総トリハロメタン}

今回の調査では水道水中の総トリハロメタン濃度（ク ロロホルム・ブロモジクロロメタン・ジブロモクロロメ タン・ブロモホルム各濃度の総計）は上水の基準值 100 $\mu \mathrm{g} / \mathrm{L}$ を回った。各自治体水道水の総トリハロメタン濃 度平均值とその標準偏差を Fig. 3 に示した。

また水道水中総トリハロメタン濃度の季節変動を Table 1 に示したが， 9 月の平均值は $31.40 \mu \mathrm{g} / \mathrm{L}$ と最も高 く, 2 月でも $29.72 \mu \mathrm{g} / \mathrm{L}$ と 9 月の平均值に近い值を示し た。な打測定した 18 地点, 72 検体の河川水からはいず れも定量限界を上回るトリハロメタン類は検出されな かった。

\section{2. トリクロロエチレンの結果}

今回の調査では 1996 年の先行研究 $(9)$ で $1.1 \sim 1.6 \mu \mathrm{g} / \mathrm{L}$ の検出例があった $\mathrm{C}$ 自治体の水道水では, 今回も継続し てトリクロロエチレンが検出された。その検出範囲は 9 月上旬の調査で $0.1 \sim 0.6 \mu \mathrm{g} / \mathrm{L}$ であり，11月下旬の調査 では最高濃度 $6.8 \mu \mathrm{g} / \mathrm{L}$ が検出された。9月に $0.6 \mu \mathrm{g} / \mathrm{L}$ 検 出された文化史跡内の水道水では 11 月に $0.6 \mu \mathrm{g} / \mathrm{L}, 2$ 月 

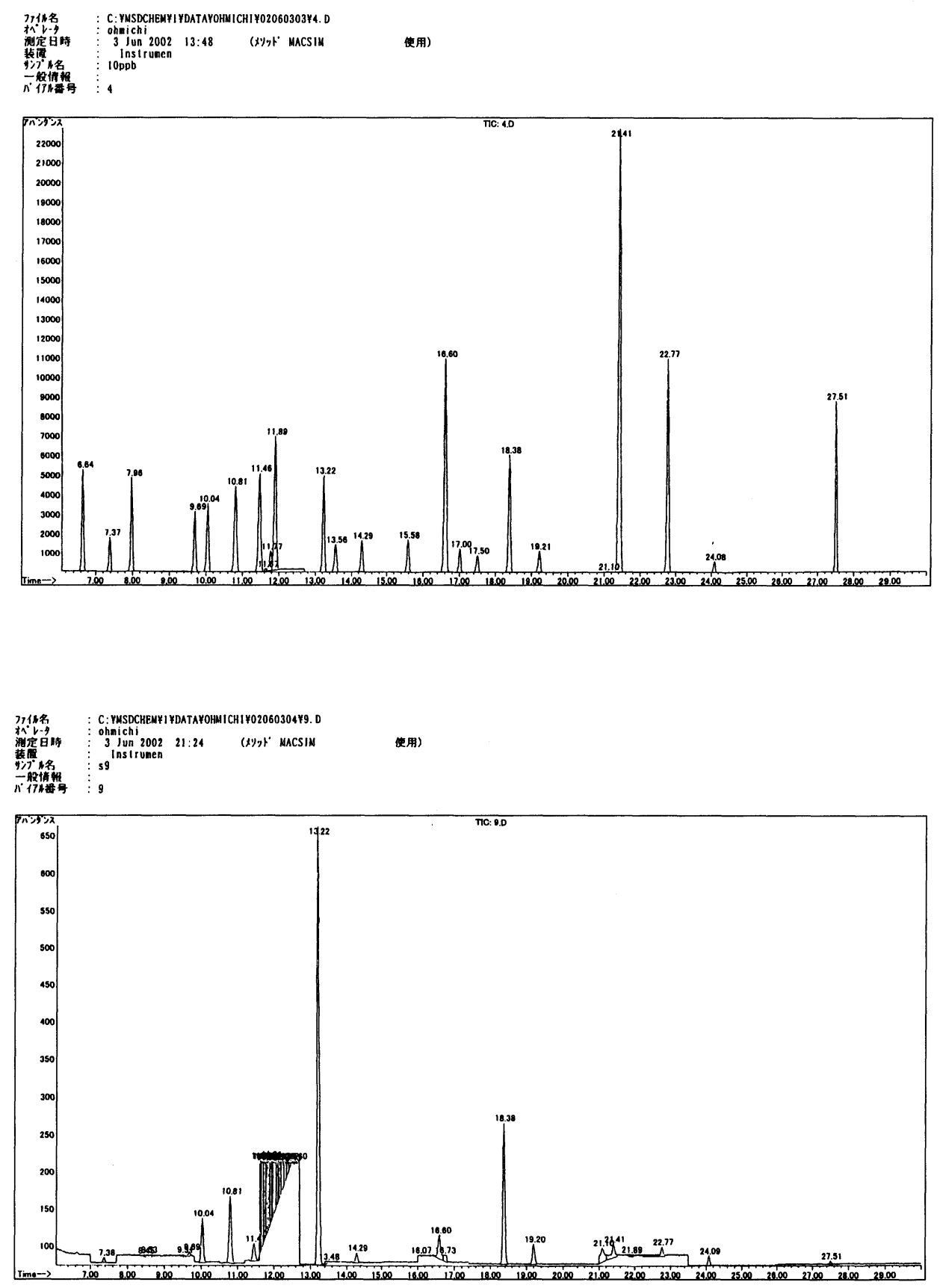

Fig. 2 Upper figure shows 23 volatile organic compounds mixture standard solution mass chromatogram. Lower figure shows tap water mass chromatogram. Hewlett-Packard 5890 series II gas chromatograph was employed. Analysis was carried out on a column $(60 \mathrm{~m} \times 0.25 \mathrm{~mm})$ of Aquatic $\left(1.0 \mu \mathrm{m}\right.$ film) with temperature programming from $40^{\circ} \mathrm{C}$ (held for $\left.2 \mathrm{~min}\right)$, to $120^{\circ} \mathrm{C}\left(4^{\circ} \mathrm{C} / \mathrm{min}\right)$, and finally to $180^{\circ} \mathrm{C}$ (held for $2 \mathrm{~min}$ ) at $10^{\circ} \mathrm{C} / \mathrm{min}$.

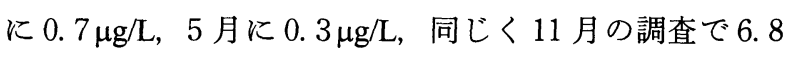
$\mu \mathrm{g} / \mathrm{L}$ 検出された大学内の水道水からも 2 月に $1.6 \mu \mathrm{g} / \mathrm{L}, 5$ 月に $0.2 \mu \mathrm{g} / \mathrm{L}$ と継続して検出された。

\section{3. $\operatorname{COD}$ の結果}

有機物の水質指標としての $\mathrm{COD}$ の調査地域に上る変 動を Fig. 4. に示す。調査河川流域の上流より下流に移行 するにしたがいCOD は上昇する傾向にあり，調査した
河川水の COD 最高值は $2.54 \mathrm{mg} / \mathrm{L}$ であった。

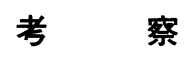

\section{1. 総トリハロメタン}

町田らが今回と同じ調查地域で 1996 年 9 月上旬に調

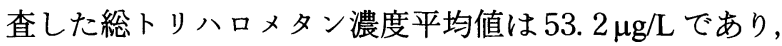
上水の水道基準值を超過したものは 3 検体であった (9)。 


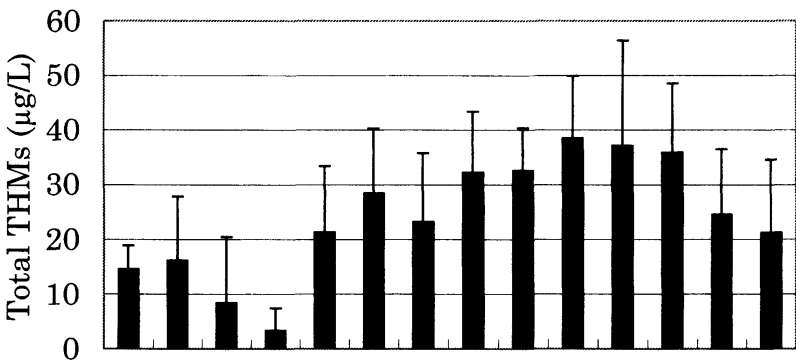

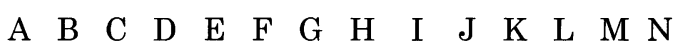

Fig. 3 The total concentration of trihalomethanes (THMs) at each local municipality. The values show mean \pm SD $(n=$ 10 13). Each local municipality letter $(A \sim N)$ corresponds to the letter in the map of Fig. 1.

同じく 5 年後の 2001 年 9 月上旬の調査では総トリハロメ タン濃度の平均值は $31.4 \mu \mathrm{g} / \mathrm{L}$ であった。今回の調査で は, 総トリハロメタン濃度は上水の総トリハロメタン濃 度基準值を超えたものはなかったことから, 現状の水質 行政による水質管理が基準値を指標にした観点では良好 であると言える。しかしながら依然として基準值以下と はいえ平均 $24.08 \mu \mathrm{g} / \mathrm{L}$ の総卜リハロメタンが水道水に含 まれている事実は注目すべきである。

Fig. 3 に示されるように, 上流地域より下流地域でトリ 八ロメタンの生成が促進されていることがらかがえる。 また調査自治体のらち水道原水に河川水を用いている自 治体は $\mathrm{A} \cdot \mathrm{B} \cdot \mathrm{F} \sim \mathrm{N}$ 自治体, 地下水を原水に用いている 自治体は $\mathrm{C} ・ \mathrm{D} ・ \mathrm{E}$ 自治体であるが，地下水を原水とする $\mathrm{C} \cdot \mathrm{D}$ 自治体水道水の総卜リハロメタン濃度が比較的低值 であったことから, 水道原水に地下水を使用する場合に はトリハロメタンの生成が抑制される可能性を示唆し た。ただし $\mathrm{E}$ 自治体水道水も地下水を原水として打り必 ずしも地下水によって総トリハロメタンの生成が抑制さ れるとは言い切れない面も認められた。

トリハロメタンは原水の有機物と浄水場で消毒に使用 される塩素との化学反応によって生成される $(6,7)$ 。こ のことから原水中に含まれる有機物が水道水に打けるト リハロメタン生成に影響を与えたことが推測される。そ こで, 原水中の有機物の水質指標である COD と水道水 中の総トリハロメタン濃度との関係を調べたが, 河川水 の COD は上流から下流に移行するのにしたがって上昇 する傾向にあり（Fig. 4）, 総トリハロメタン濃度が上流

Table 1 Seasonal changes of the total concentration of trihalomethanes (THMs) in tap water

\begin{tabular}{lc}
\hline \multicolumn{1}{c}{ Month } & Average: (Range) $\mu \mathrm{g} / \mathrm{L}$ \\
\hline September 2001 & $31.40:(8.63 \sim 54.03)$ \\
November 2001 & $17.90:(1.16 \sim 43.80)$ \\
February 2002 & $29.72:(0.09 \sim 75.55)$ \\
May 2002 & $17.30:(0.14 \sim 33.67)$ \\
Overall average & $24.08:(0.09 \sim 75.55)$ \\
\hline
\end{tabular}

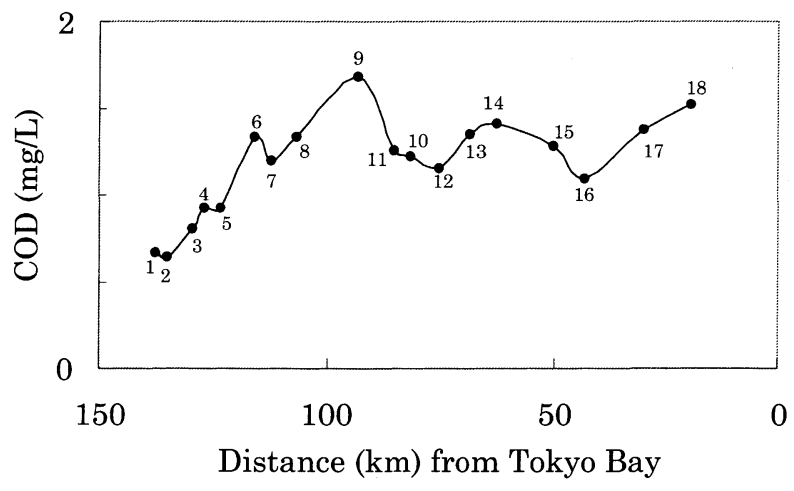

Fig. 4 Changes in seasonal average values $(O)$ of chemical oxygen demand (COD) against distance from Tokyo Bay in the river system of Watarase, Tone and Edo rivers at eighteen sampling points. Each number (1 18) corresponds to the number in the map of Fig. 1.

地域から下流地域に移行するにしたがい上昇する結果 （Fig. 3）と同様な傾向であった。しかし水道水中総卜リ 八ロメタン濃度とその原水の COD との間には有意な相 関はなかった。また今回データでは示さないものの, ト リハロメタン生成に関与している各種要因である水道水 中に打塩素イオン濃度および残留塩素濃度のトリ八 ロメタン生成への寄与を検討したが，これらとトリハロ メタン濃度との両間には有意な相関は存在しなかった。 これは, トリハロメタンの生成機構を単一のファクター によってのみで説明することが難しいためである。トリ 八ロメタンの生成要因は原水の有機物や浄水場での塩素 消毒による遊離塩素に加えて, 水道管での塩素曝露時間 や $\mathrm{pH}$ ・温度などが相互的に関与すること $(13,14)$ から, 今回総トリハロメタン濃度と各生成要因との相関が得ら れなかったと考えられる。

また, トリハロメタンの季節変動については, 気温が 高い夏期に生成が促進され, 総卜リハロメタン濃度が高 値を示す傾向にあると仮定したが，9月のみならず 2 月 にも総トリハロメタン濃度が高値を示した。このことは, トリハロメタンの生成が水温にのみ依存しないことを示 咍するものである。9月の調査での総トリハロメタン濃 度が高值を示したことはトリハロメタンが高温下で生成 が促進されたためであるとも考兄らるが，2月におけ る高値は, 夏期に比べ冬期では気温があまり高くないた め塩素が揮発することなく残留し, トリハロメタンの生 成を促進したものとも推測されるが，不確かなところで もある。

トリハロメタン生成能に関しては, 冬期と夏期で大 きな差は認められなかったとの報告がある(15)。本研究 では生成能については検討できていないが，今回の結果 から, 高温に晒されトリハロメタンの生成が促進されや すい環境下である夏期においてだけでなく年間を通じて トリハロメタン生成の監視が必要であると考えられる。 また 2 月に総トリハロメタン濃度が高く検出されたこと 
はトリハロメタンの生成には温度以外に原水中有機物・ 浄水由来の残留塩素・水道管での曝露時間などが相互的 に関与していることを示唆している。

Fig. 3 では各自治体水道水の総卜リハロメタン濃度平 均值とその標準偏差を示したが， $\mathrm{N}$ 自治体では下流地域 の中では比較的低い濃度であった。これは $\mathrm{N}$ 自治体が, 高度浄水処理システム（オゾン処理）を導入した浄水場 より得られた水道水を用いていることから, その効果で あることがうかがわれる。

\section{2. トリクロロエチレン}

$\mathrm{C}$ 自治体ではトリクロロエチレンが常に検出されてい る。この地域では水道水の原水として地下水を利用して いる。今回地下水を直接サンプルとして採水し検査を 行ったわけではないので断定はできないが, この地域の トリクロロエチレンによる地下水污染が疑われた。国は 塩素化合物の地下水污染調查を行い全国的に揮発性有機 塩素化合物污染が極めて広範囲に及んでいることを 1983 年に明らかにした（16）。最近の国の報告でも污染状 況は改善されつつあるとはいえ依然として広範囲な地域 での地下水污染が確認されている(17)。今回の調査で も, 水道水中では 1996 年と同様に依然として C 自治体で トリクロロエチレンの污染が続いていることが明らかに なった。以上から地下水は, ひとたび污染されると回復 が困難であると言えよう。また污染源としては工場廃水・ ドライクリーニング廃液等による環境排出が考えられる が，污染源の特定はできていない。

\section{終わりに}

わが国の水道水質は, トリハロメタン污染に加え農薬 などの化学物質や内分泌かく乱化学物質污染など新たな 水道水質問題が注目されるよらにもなった (18)。そこで 我々は現在これら諸問題も視野に入れ本調査と同じ調査 地域で継続調査中である (19)。現時点ではまだ充分な実 態把握とは言えないが本調査によっていくつかの問題点 を提示できる。まず浄水場での浄水処理によって河川水 では存在していなかったトリハロメタン類を生成させ水 道水污染を引き起こしている事実を再確認できた上，水 道水からのトリクロロエチレンの検出に代表されるよう に原水における揮発性有機化合物污染が懸念された。こ れら物質が浄水過程では充分除去されることなく水道水 中に移行することが示唆された。したがって良質な水道 水供給のためには一層の浄水・給水技術の向上が必要と いえる。さらには浄水・給水技術には限界もあることか ら, 原水となる河川水・地下水の水資源の環境保全が最 も重要である。

\section{謝辞}

稿を終えるにあたり，ご指導とご助言賜りました千葉
市環境保健研究所奥村修平先生, 塚原 滋先生, 調査に ご協力いただいた早稲田大学の大野千尋さん, 曽根広行 さん，壽 和輝さん，岩花永以子さん，酒井秀人さん， 平川美さん，山崎享子さんに心より感謝いたします。

\section{文献}

（1）中西準子. 水の環境戦略. 東京: 岩波新書, 1999.

（2）中本信忠. 生でおいしい水道水. 東京 : 築地書館, 2002.

( 3 ) Cantor KP, Lynch CF, Hildesheim ME, Dosemeci M, Lubin J, Alavanja M, Craun G. Drinking water source and chlorination byproducts. I. Risk of bladder cancer. Epidemiology 1998; 9(1) : 21-28.

(4) King WD, Marrett LD, Woolcott CG. Case-Control study of colon and rectal cancers and chlorination by-products in treated water. Cancer Epidemiol Biomarkers Prev 2000; $9(8)$ : 813-818.

( 5 ) Sanukida S, Nobukawa T, Ichihara M, Shima H, Inoue K, Nakachi S. Evaluation of formation potential of trihalomethanes and mutagens due to chlorination of river water along the Kizu River in the Yodo River system in Japan. Limnology $2001 ; 2$ (3) : 169-177.

（6）米国環境保護庁編・眞柄泰基. 飲料水とトリハロメタ ン制御. 東京 : 公害対策技術同友会, 1985 .

（7）丹保憲仁. 水道とトリハロメタン. 東京 : 技報堂出版, 1995.

( 8 ) Rook JJ. Formation of haloforms during chlorination of natural waters. J Water Treat Exam 1974; 23: 234-243.

（9）町田和彦, 黛 陽子. 渡良瀬川, 利根川, 江戸川水系 での河川の污染と水道水 第 3 報. 日本衛生学雑誌 1997; 52(1) : 296.

（10）大道公秀, 町田和彦. 河川水と水道水との関係性に関 する研究成果. 体力・栄養・免疫学雑誌 $2001 ; 11$ (2): A69-70.

(11) National Cancer Institute. Carcinogenesis bioassay of trichloroethylene,Carcionogenesis Technical Report Series No. 2. New York: DHEW Publication, 1976: No. $<$ NIH $>$ 76-802.

（12）日本薬学会. 衛生試験法・注解. 東京, 金原出版, 2001.

（13）水道協会. 上水試験方法 2001 年度. 東京, 水道協会, 2001.

（14）梶野勝司. 塩素処理におけるトリハロメタンの形成. 水道協会雑誌 $1977 ; 514: 17-36$

（15）内山征洋, 中島 右, 氏家淳雄. トリハロメタン生成 特性による利根川, 上, 中流域の水質評価（2）冬期 および夏期に打けるトリ八ロメタン生成能調査結果. 群馬県衛生公害研究所年報 1984; 93-95.

（16）杉戸大作. 地下水污染. 水道協会雑誌 1983；589：5361.

（17）環境省環境管理局水環境部. 地下水 - 地盤環境の現況 について〜平成 13 年第 2 回中央環境審議会水環境部 会参考資料 10，東京：環境省， 2001 .

（18）荒井真一. 水道水質管理を巡る最近の動向－化学物 質, 病原性微生物対策を中心として. 空気調和・衛生 工学 $2000 ; 74(6): 443-450$.

（19）大道公秀, 大道正義, 町田和彦. 渡良瀬川 - 利根川 - 
日衛誌 (Jpn. J. Hyg.) 第 59 巻 第 1 号 2004 年 1 月

江戸川流域での河川水および水道水の水質に関する 追跡研究 (中間報告), 日本学術会議 第 6 回水資源に

関するシンポジウム 2002 ; シンポジウム論文集 $744-$ 749 . 